\title{
Analysis of the clinical and molecular characteristics of a child with achondroplasia: A case report
}

\author{
JINGFANG LIU, XULEI TANG, JIANGUO CHENG, LITING WANG, XIAOMEI YANG and YAN WANG \\ Department of Endocrinology, The First Hospital of Lanzhou University, Lanzhou, Gansu 730000, P.R. China
}

Received June 17, 2014; Accepted January 26, 2015

DOI: $10.3892 /$ etm.2015.2324

\begin{abstract}
Achondroplasia $(\mathrm{ACH})$ is a hereditary dwarfism caused by the disturbed proliferation and differentiation of growth plate chondrocytes, followed by impaired endochondral bone growth. $\mathrm{ACH}$ is caused by mutations in the gene encoding the transmembrane receptor, fibroblast growth factor receptor 3 (FGFR3). In total, $>90 \%$ of patients with $\mathrm{ACH}$ have a G1138A mutation in the transmembrane domain of the FGFR3 gene. Patients with ACH usually have no growth hormone $(\mathrm{GH})$ deficiency. The current study presents the case of a four-year-old male with clinical manifestations suggestive of $\mathrm{ACH}$, including a large head, prominent forehead, short upper arms and legs, and short hands with fingers assuming a trident position. The patient showed normal responses to $\mathrm{GH}$ provocation tests with L-dopa (peak GH concentration, $42.38 \mathrm{ng} / \mathrm{ml}$ ) and insulin (peak GH concentration, $23.29 \mathrm{ng} / \mathrm{ml}$ during hypoglycemia), but a blunted response to a $\mathrm{GH}$ provocation test with arginine (peak GH concentration, $7.31 \mathrm{ng} / \mathrm{ml})$. Furthermore, the GH concentration during exercise was low $(4.8 \mathrm{ng} / \mathrm{ml})$. Magnetic resonance imaging revealed a decreased pituitary volume. Thyroid function tests and the levels of sex hormones (follicle stimulating hormone, luteinizing hormone, estradiol, prolactin and progesterone), cortisol and adrenocorticotropic hormone were normal. A heterozygous G1138A mutation within the FGFR3 gene was detected, confirming the diagnosis of $\mathrm{ACH}$. Thus, recombinant human $\mathrm{GH}$ therapy $(0.1 \mathrm{IU} / \mathrm{kg} /$ day) was initiated. At the six-month follow-up, the height, arm span-to-height ratio and lower limb length-to-height ratio of the patient had increased, while the head circumference had decreased. The present results corroborate the finding that the G1138A mutation within FGFR3 is the most common $\mathrm{ACH}$-causing mutation in different populations. GH may be beneficial in the treat-
\end{abstract}

Correspondence to: Miss. Jingfang Liu, Department of Endocrinology, The First Hospital of Lanzhou University, 1 Donggang West Road, Lanzhou, Gansu 730000, P.R. China E-mail address: ljf824168@126.com

Key words: achondroplasia, fibroblast growth factor receptor 3, mutation, grow th hormone ment of short stature in $\mathrm{ACH}$ patients with subnormal GH secretion.

\section{Introduction}

Achondroplasia $(\mathrm{ACH})$ is a hereditary dwarfism caused by a disturbance in the proliferation and differentiation of growth plate chondrocytes, followed by an impairment in endochondral bone growth. The incidence rate of $\mathrm{ACH}$ is $\sim 1 / 15-40,000$ live births (1). In total, between 80 and $90 \%$ of $\mathrm{ACH}$ cases are sporadic (2). Newborn infants with ACH typically present with disproportionate shortening of the limbs, a long and narrow trunk, a large head with frontal bossing and midfacial hypoplasia. The hands are short and broad, and frequently exhibit a three-pronged (trident) configuration. Furthermore, numerous joints, with the exception of the elbow, are hyperextensible (3). The disease shows an autosomal dominant inheritance and is caused by mutations in the gene encoding the transmembrane receptor, fibroblast growth factor receptor 3 (FGFR3), which is an important regulator of linear bone growth. FGFR3 is expressed in various tissues including the cartilage, brain, kidneys and the intestines at different stages of development. FGFR3 mutations generate deficient proteins that affect chondrocyte proliferation and calcification, and hinder cartilage growth and development, thereby resulting in an external phenotype of ACH (4). The human FGFR3 gene is located on chromosome $4 \mathrm{q} 16.3$. In total, $>90 \%$ of patients with $\mathrm{ACH}$ have a G1138A mutation in the transmembrane domain of the FGFR3 gene $(5,6)$. Research on ACH began later in China than in Europe and the US. Currently, almost 60 clinical cases have been reported around the country and there have been no studies, to the best of our knowledge, on the incidence rate of $\mathrm{ACH}$ in China. In the present study, the clinical characteristics of a Chinese male child diagnosed with $\mathrm{ACH}$ were analyzed, and tests for the FGFR3 gene mutation were performed on the patient and patient's family.

\section{Case report}

Patient characteristics and clinical observations. A four-year-old male was admitted to the First Hospital of Lanzhou University (Lanzhou, China) with growth retardation since the age of three years. The patient was an only child, and was born at full term via vaginal delivery with a birth weight of 3,900 g. Teething began between seven and eight 
months, and the patient was walking at one year. After one year of age, it was noted that the patient's growth and development were slow, and that his height was lower compared with other children of a similar age. The annual increase in height was $<5 \mathrm{~cm}$; however, the weight and intelligence level were normal. A physical examination at the time of admission revealed the following characteristics: Body temperature, $36^{\circ} \mathrm{C}$; pulse rate, $90 \mathrm{bpm}$; respiratory rate, 20 breaths $/ \mathrm{min}$; height, $85 \mathrm{~cm}$; and weight, $16 \mathrm{~kg}$. The patient had a large head with a prominent forehead. In addition, there was disproportionate shortening of the upper arms and legs, and the patient had short hands with fingers that assumed a three-pronged (trident) configuration.

Laboratory results were as follows: Serum calcium, $2.41 \mathrm{mmol} / 1$ (normal range, 2.10-2.80 $\mathrm{mmol} / 1$ ); serum phosphorus, $1.66 \mathrm{mmol} / 1$ (normal range, 0.97-1.60 mmol/1); intact parathyroid hormone, $24.20 \mathrm{pg} / \mathrm{ml}$ (normal range, 14-72 pg/ml); 25-hydroxy vitamin D, $72.6 \mathrm{nmol} / 1$ (normal range, 47.7-144 nmol/1); osteocalcin, $38.8 \mathrm{ng} / \mathrm{ml}$ (normal range, $12.8-55 \mathrm{ng} / \mathrm{ml}$ ); bone-specific alkaline phosphatase, $89.7 \mathrm{ng} / \mathrm{ml}$ (normal range, 7.3-22.4 ng/ml); urine calcium, $1.30 \mathrm{mmol} / 24 \mathrm{~h}$ (normal range, $2.5-7.5 \mathrm{mmol} / 24 \mathrm{~h}$ ); urine phosphorus, $13.75 \mathrm{mmol} / 24 \mathrm{~h}$ (normal range, $23-48 \mathrm{mmol} / 24 \mathrm{~h}$ ); thyroid-stimulating hormone (TSH), $1.26 \mu \mathrm{IU} / \mathrm{ml}$ (normal range, $0.55-4.78 \mu \mathrm{IU} / \mathrm{ml})$; triiodothyronine $\left(\mathrm{T}_{3}\right), 1.69 \mathrm{ng} / \mathrm{ml}$ (normal range, $0.60-1.81 \mathrm{ng} / \mathrm{ml}$ ); thyroxine $\left(\mathrm{T}_{4}\right), 10.0 \mu \mathrm{g} / \mathrm{dl}$ (normal range, 4.50-10.9 $\mu \mathrm{g} / \mathrm{dl}$ ); free $\mathrm{T}_{3}, 4.19 \mathrm{pg} / \mathrm{ml}$ (normal range, $2.3-4.2 \mathrm{pg} / \mathrm{ml}$ ); and free $\mathrm{T}_{4}, 1.34 \mathrm{ng} / \mathrm{dl}$ (normal range, $0.89-1.76 \mathrm{ng} / \mathrm{dl}$ ). Test for antibodies against the TSH receptor, thyroid peroxidase and thyroglobulin were negative. In addition, the levels of sex hormones, cortisol and adrenocorticotropic hormone (ACTH) were normal. The patient's karyotype was 46,XY. A radiograph of the upper limbs and hands revealed the hands to be short and broad, with a trident configuration, and that the estimated age of the wrist bones was lower than the actual age of the patient (Fig. 1A). A radiograph of the lower limbs revealed disproportionate shortening of the limbs, bilateral trumpet-like enlargement of the distal femoral metaphyses and blurring of the epiphyseal shape (Fig. 1B). Furthermore, a magnetic resonance imaging (MRI) scan revealed a decreased pituitary volume and a hyperintense and spot-like corpus callosum, indicative of malacia, on the T1- and T2-weighted images. No similar phenotype was identified in the parents or other family members (grandfather, grandmother, aunts, uncles and cousins) of the patient.

Growth hormone provocation tests. Growth hormone (GH) responses to provocation tests $(0.1 \mathrm{IU} / \mathrm{kg}$ insulin-induced hypoglycemia, $10 \mathrm{mg} / \mathrm{kg}$ L-dopa and $0.5 \mathrm{~g} / \mathrm{kg}$ arginine) and the levels of GH during exercise (brisk walking for 15 minutes followed by running for $5 \mathrm{~min}$ with the heart rate reaching $>120$ beats/min; GH levels obtained 20 min after exercise initiation) were evaluated. Serum GH concentrations were determined using an immunoradiometric assay (Tianjin Nine Tripods Medical \& Bioengineering Co., Ltd., Tianjin, China). The intra-assay variation was $<5.8 \%$ and the inter-assay variation was $<9.3 \%$. The responses of cortisol and ACTH to insulin-induced hypoglycemia were evaluated simultaneously.

Peak GH levels of $<10 \mathrm{ng} / \mathrm{ml}$ on $\mathrm{GH}$ provocation tests with insulin, L-dopa and arginine, and a $\mathrm{GH}$ level of $<5 \mathrm{ng} / \mathrm{ml}$ during exercise were defined as blunted GH secretion, according to the criteria of the Foundation for Growth and Science in China (7).

Genomic DNA extraction. A 2-ml sample of peripheral venous blood was collected from the patient, his parents and seven healthy controls ( 3 females and 4 males, aged 10-35 years) who were volunteers that were in the hospital for a physical examination. DNA was isolated from the blood samples using a Blood Genome DNA Extraction kit (Takara Biotechnology Co., Ltd., Dalian, China), and subsequently dissolved in Tris-EDTA buffer (Takara Biotechnology Co., Ltd.) and stored at $-20^{\circ} \mathrm{C}$ until required for further use.

DNA amplification and mutation detection. Exon 10 of the FGFR3 gene was amplified using polymerase chain reaction (PCR; Roche Diagnostics Co., Ltd., Shanghai, China). The sequence of the forward primer was 5'-AGGCGCGTGCTGAGGTTCTGAG-3' and the sequence of the reverse primer was 5'-GGAGATCTTGTGCACGGTGG-3'. (Sangon Biotech Co., Ltd., Shanghai, China) All PCR amplifications were performed in a total volume of $50 \mu \mathrm{l}$, which contained $2 \mu \mathrm{l}$ extracted DNA, 20 pmol each of the forward and reverse primers, $19 \mu \mathrm{l}$ 2X Taq PCR Master mix (Takara Biotechnology Co., Ltd.) and $25 \mu$ l deionized water. Thermal cycling conditions were as follows: Initial activation of DNA polymerase at $95^{\circ} \mathrm{C}$ for $5 \mathrm{~min}$, followed by 30 cycles of $95^{\circ} \mathrm{C}$ for $30 \mathrm{~min}, 58^{\circ} \mathrm{C}$ for $30 \mathrm{~min}$ and $72^{\circ} \mathrm{C}$ for $45 \mathrm{~min}$, and a final extension at $72^{\circ} \mathrm{C}$ for $5 \mathrm{~min}$. The PCR products were purified by a UNIQ-10 Column kit (Sangon Biotech Co., Ltd.) and sequenced directly on a ABI3730XL genetic analyzer (Applied Biosystems Life Technologies, Foster City, CA, USA) to detect the gene mutations. The sequence results were contrasted with the normal sequence of the FGFR3 gene obtained from GenBank. All mutations were confirmed through forward and reverse sequencing.

Ethics statement. Written informed consent was obtained from the patient's family. The study was approved by the Human Ethics Review Committee of the First Hospital of Lanzhou University and complied with the Declaration of Helsinki for Experimentation on Humans, 1975 (revised in 1983).

\section{Results}

GH provocation tests. GH responses to the provocation tests are shown in Fig. 2. The patient showed normal responses to the GH provocative tests using L-dopa (peak GH concentration, $42.38 \mathrm{ng} / \mathrm{ml}$ ) and insulin (peak GH concentration was increased to $23.29 \mathrm{ng} / \mathrm{ml}$ during hypoglycemia). However, a slightly blunted response was observed for the $\mathrm{GH}$ provocation test with arginine [peak GH concentration, $7.31 \mathrm{ng} / \mathrm{ml}(<10 \mathrm{ng} / \mathrm{ml})]$, and the $\mathrm{GH}$ level during exercise was low $[4.8 \mathrm{ng} / \mathrm{ml}(<5 \mathrm{ng} / \mathrm{ml})]$. The cortisol and ACTH responses to insulin-induced hypoglycemia were normal.

Gene mutation analysis. Gene mutation analysis revealed that the patient had a $\mathrm{G} \rightarrow \mathrm{A}$ mutation at nucleotide 1,138 within exon 10 of the FGFR 3 gene. This missense mutation caused the substitution of glycine with arginine at amino acid posi- 

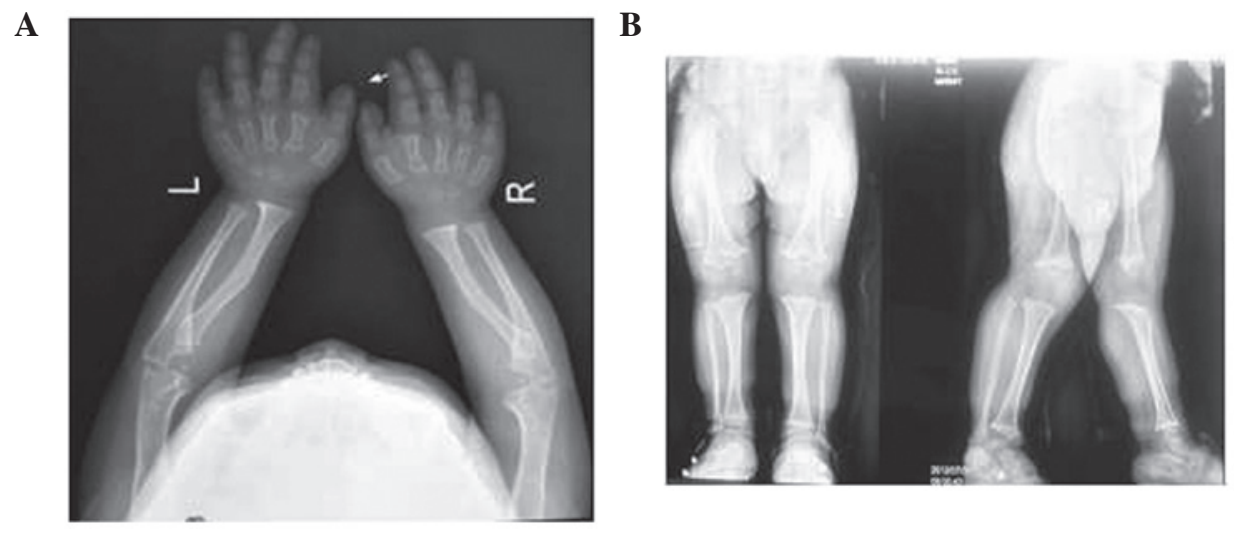

Figure 1. Radiographs of the upper and lower limbs. (A) Hands are short and broad, and exhibit a three-pronged configuration. The estimated age of the wrist bones is lower than the actual age of the patient. (B) Lower limbs show disproportionate shortening, bilateral trumpet-like enlargement of the distal femoral metaphyses and blurring of the epiphyseal shape.
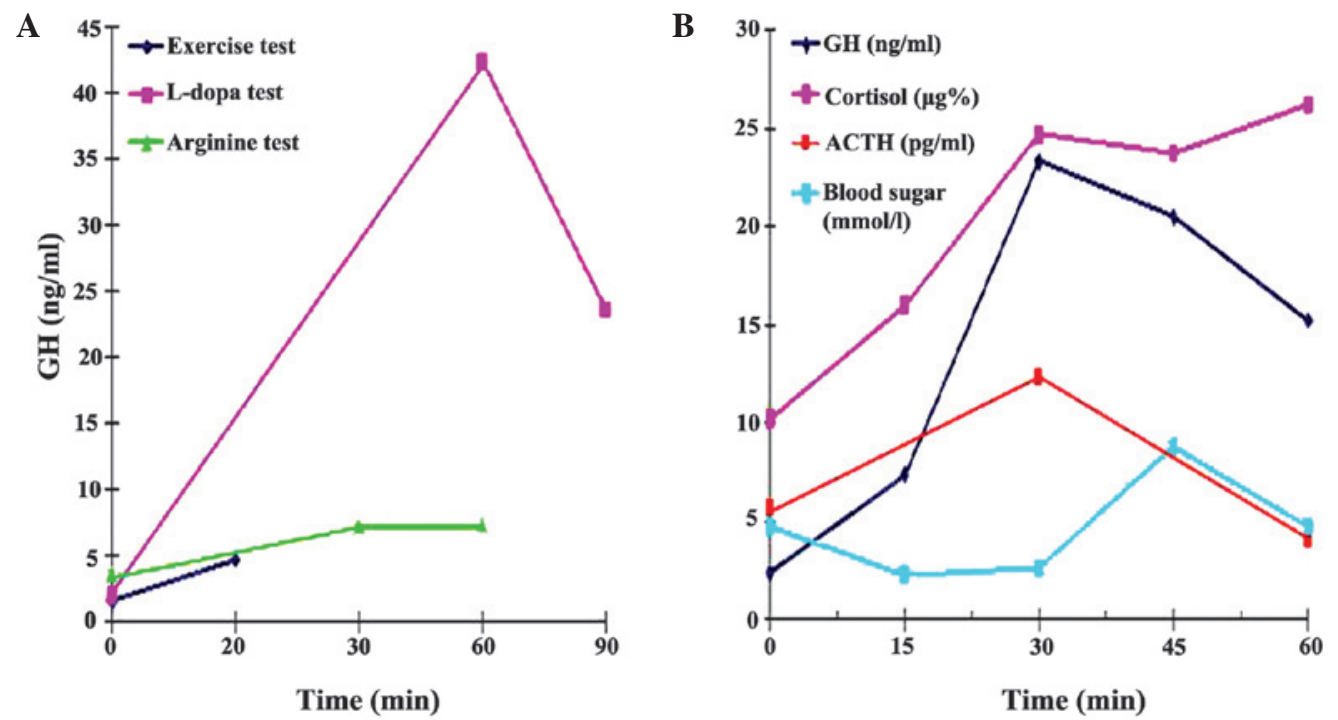

Figure 2. GH response to the provocation tests. (A) GH concentrations following the provocation tests with L-dopa and arginine, and during exercise. (B) Response of cortisol, GH and ACTH to insulin-induced hypoglycemia. GH, growth hormone; ACTH, adrenocorticotropic hormone.

A
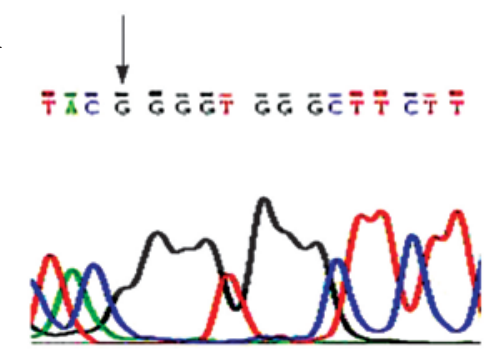

C $\bar{T} \bar{A} \bar{C} \bar{C} \bar{G} \bar{G} \bar{G} \bar{T} \bar{G} \bar{G} \bar{G} \bar{C} \bar{T} \bar{T} \bar{C} \bar{T} \bar{T}$

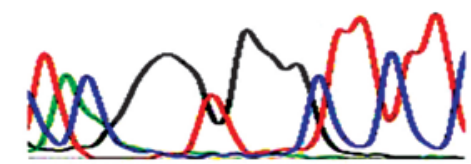

B

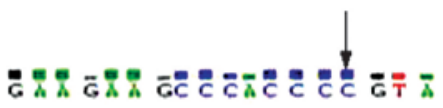

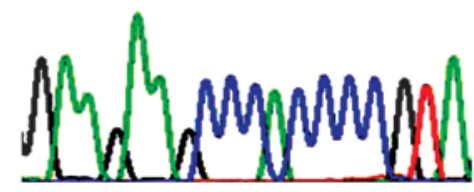

D

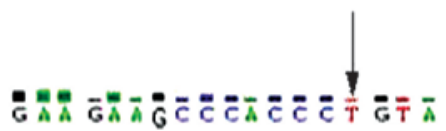

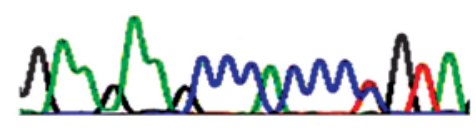

Figure 3. Partial sequencing results of the polymerase chain reaction products of exon 10 in the fibroblast growth factor receptor 3 gene. (A) Normal control (forward sequencing), homozygote GG. (B) Normal control (reverse sequencing), homozygote CC. (C) Patient with achondroplasia (ACH; forward sequencing), heterozygous AG. (D) Patient with ACH (reverse sequencing), heterozygous TC. The arrows indicate mutated bases. 
tion 380 (G380R) in the FGFR3 protein. The mutation was heterozygous, and the results of the forward and reverse sequencing were consistent (Fig. 3). No mutation within exon 10 of the FGFR3 gene was observed in the samples taken from the patient's parents or from seven healthy controls (aged 10-35 years) from the First Hospital of Lanzhou University.

Treatment and follow-up . A diagnosis of $\mathrm{ACH}$ with subnormal $\mathrm{GH}$ secretion was considered on the basis of the clinical and laboratory results. Oral therapy with recombinant human grow th hormone (rhGH; $0.1 \mathrm{IU} / \mathrm{kg} / \mathrm{day}$ ) and levothyrocine (12.5 $\mu \mathrm{g} / \mathrm{day})$ was initiated. After six months, the patient's height had markedly improved (to $93.5 \mathrm{~cm}$ ). Furthermore, the arm span-to-height ratio and lower limb length-to-height ratio increased during treatment, while the head circumference decreased. The serum GH concentration was $60.37 \mathrm{ng} / \mathrm{ml}$. No abnormality was found on the thyroid function and sex hormone tests.

\section{Discussion}

$\mathrm{ACH}$, an autosomal dominant disorder, is the most common form of human dwarfism. The main clinical manifestation is an abnormally large head with a prominent forehead and flat nasal bridge, short upper arms and legs (rhizomelic dwarfism), an unusually prominent abdomen and buttocks, and short hands with fingers that assume a trident or three-pronged position during extension. In 1994, Francomano et al located the pathogenic gene of $\mathrm{ACH}$ to chromosome 4p16.3 through genetic linkage analysis (8). Soon after, Shiang et al reported a missense mutation at codon 380 in the transmembrane domain of the FGFR3 gene in patients with $\mathrm{ACH}(5,6) . \mathrm{A} \mathrm{G} \rightarrow \mathrm{A}$ displacement at nucleotide 1,138 in the FGFR3 gene is present in $90 \%$ of patients with $\mathrm{ACH}$, while a $\mathrm{G} \rightarrow \mathrm{C}$ transversion is present in only a minority of patients $(9,10)$. Similar results have been reported in Chinese populations (11). G375C and G346E mutations on the transmembrane domain of the FGFR3 gene have also been observed in patients with $\mathrm{ACH}(12,13)$. These results indicate a strong association between the transmembrane domain of the FGFR3 gene and ACH. Furthermore, Zhang et al reported a Ser217Cys mutation in the Ig II domain of the FGFR3 gene in a Chinese family with ACH (14).

FGFR3, a type of tyrosine receptor, comprises 806 amino acid residues and plays an important role in skeletal development. The length of the FGFR3 gene is $\sim 15 \mathrm{~kb}$, with 19 exons and 10 introns. Exon 10 encodes the transmembrane domain of the FGFR3 gene. As a membrane receptor, the structure of FGFR3 is comprised of three parts, including an intracellular region, a transmembrane domain and an extracellular region, the latter of which functions as a binding domain for numerous ligands, including three typical Ig-like structural domains (Ig I-III) (15). The intracellular region includes a near-membrane area, two conservative tyrosine kinase functional domains and an autophosphorylated C-terminal. The ligand, fibroblast growth factor (FGF), may attach to acetylated proteins on the surface of the cells and induce receptor dimerization and transautophosphorylation of the tyrosine kinase in the cytoplasm (16). The residual phosphate cellulose may be used as a docking site for proteins, subsequently resulting in the activation of various signaling pathways that mediate the effects of the FGF receptor with regard to the regulation of proliferation, differentiation and apoptosis in a number of cells (16).

In the present case report, the patient demonstrated clinical manifestations similar to those described in the literature on $\mathrm{ACH}$, including a large head, prominent forehead, short upper arms and legs, and short hands with fingers that assumed a trident position. The results of the imaging examinations were also consistent with a diagnosis of $\mathrm{ACH}$. Finally, a $\mathrm{G} \rightarrow \mathrm{A}$ displacement at nucleotide 1,138 within exon 10 of the FGFR3 gene was identified, which further confirmed that nucleotide 1,138 within the FGFR3 gene is a common site of mutations leading to $\mathrm{ACH}$. The main reason that the FGFR3 mutation leads to $\mathrm{ACH}$ may be the suppression of the proliferation and differentiation of cartilage cells. The FGFR3 mutation causes dimerization of cell membrane proteins, and may lead to the continuous activation of intracellular tyrosine kinases in the absence of a ligand, which ultimately activates intracellular signaling pathways and suppresses the proliferation and differentiation of cartilage cells $(17,18)$. Matsushita et al reported that the extracellular signal-regulated kinase/mitogen-activated protein kinase signaling pathway in cartilage cells plays an important role in the development of $\mathrm{ACH}$ (19).

Patients with ACH do not generally have a GH deficiency (20). In the current study, the patient demonstrated a normal response to $\mathrm{GH}$ provocation tests with L-dopa and insulin; however, a blunted response was observed in the $\mathrm{GH}$ provocation test with arginine (peak $\mathrm{GH}$ concentration, $<10 \mathrm{ng} / \mathrm{ml})$. In addition, low $\mathrm{GH}$ concentrations were observed during exercise $(<5 \mathrm{ng} / \mathrm{ml})$. Therefore, a subnormal GH secretion was suspected. Furthermore, an MRI scan revealed that the pituitary volume was decreased. Therefore, therapy with $\mathrm{rhGH}(0.1 \mathrm{IU} / \mathrm{kg} /$ day $)$ was initiated, and marked results were observed within six months, which is consistent with previous studies (21-24). A large-scale study in Japan demonstrated that rhGH therapy promoted bone growth in patients with $\mathrm{ACH}$ by improving the $\mathrm{Z}$ scores for growth rate and height, and also had a dose- and time-dependent effect on $\mathrm{ACH}$ (25). A possible mechanism underlying the effects of $\mathrm{GH}$ treatment on $\mathrm{ACH}$ may be through the epiphyseal growth plate, which is the area of bone formation. GH stimulates local cartilage cells in this area to produce insulin-like growth factors, which promotes cartilage cell proliferation and thereby promotes growth (26).

In the present study, no mutation was observed in the FGFR3 gene of the patient's parents, indicating that the patient had a de novo mutation. $\mathrm{ACH}$ has been associated with advanced paternal age (2). As sperm cells are produced constantly throughout life, the risk of mutations in the sperm cells increases with age (21). This suggests that factors influencing DNA replication and repair during spermatogenesis may predispose to the occurrence of $\mathrm{ACH}$-associated mutations. Therefore, the mutation in the current patient was likely attributable to mutations in the father's sperm cells.

In conclusion, the results of the present study further support the hypothesis that the G1138A mutation within the FGFR3 gene is the most common mutation causing $\mathrm{ACH}$ in various populations. For certain ACH patients with subnormal GH secretion, GH therapy may be beneficial for the treatment of short stature. 


\section{References}

1. Placone $\mathrm{J}$ and Hristova K: Direct assessment of the effect of the Gly380Arg achondroplasia mutation on FGFR3 dimerization using quantitative imaging FRET. PLoS One 7: e46678, 2012.

2. Orioli IM, Castilla EE and Barbosa-Neto JG: The birth prevalence rates for the skeletal dysplasias. J Med Genet 23 . 328-332, 1986

3. Horton WA, Hall JG and Hecht JT: Achondroplasia. Lancet 370: $162-172,2007$

4. Su N, Xu X, Li C, et al: Generation of Fgfr3 conditional knockout mice. Int J Biol Sci 6: 327-332, 2010.

5. Shiang R, Thompson LM, Zhu YZ, et al: Mutations in the transmembrane domain of FGFR3 cause the most common genetic form of dwarfism, achondroplasia. Cell 78: 335-342, 1994.

6. Rousseau F, Bonaventure J, Legeai-Mallet L, et al: Mutations in the gene encoding fibroblast growth factor receptor-3 in achondroplasia. Nature 371: 252-254, 1994.

7. Li YQ, Li QL and Zhang MH: Comparison of diagnostic value of growth hormone exercise test and growth hormone provocative test on growth hormone deficiency. J Appl Clin Pediatr 24: 601-602, 2009

8. Francomano CA, Ortiz de Luna RI, Hefferon TW, et al: Localization of the achondroplasia gene to the distal $2.5 \mathrm{Mb}$ of human chromosome 4p. Hum Mol Genet 3: 787-792, 1994.

9. He X, Xie F and Ren ZR: Rapid detection of G1138A and G1138C mutations of the FGFR3 gene in patients with achondroplasia using high-resolution melting analysis. Genet Test Mol Biomarkers 16: 297-301, 2012.

10. Pehlivan S, Ozkinay F, Okutman O, et al: Achondroplasia in Turkey is defined by recurrent G380R mutation of the FGFR3 gene. Turk J Pediatr 45: 99-101, 2003.

11. Cui Y, Zhao H, Liu Z, Liu C, Luan J, Zhou X and Han J: A systematic review of genetic skeletal disorders reported in Chinese biomedical journals between 1978 and 2012. Orphanet J Rare Dis 7: 55, 2012.

12. Superti-Furga A, Eich G, Bucher HU, Wisser J, Giedion A, Gitzelmann R and Steinmann B: A glycine 375-to-cysteine substitution in the transmembrane domain of the fibroblast growth factor receptor-3 in a new born with achondroplasia. Eur J Pediatr 154: 215-219, 1995.

13. Prinos P, Kilpatrick MW and Tsipouras P: A novel G346E mutation in achondroplasia. Pediatr Res 37: 151A, 1994.
14. Zhang SR, Zhou XQ, Ren X, et al: Ser217Cys mutation in the Ig II domain of FGFR3 in a Chinese family with autosomal dominant achondroplasia. Chin Med J (Engl) 120: 1017-1019, 2007.

15. Coutts JC and Gallagher JT: Receptors for fibroblast growth factors. Immunol Cell Biol 73: 584-589, 1995.

16. Mohammadi M, Dikic I, Sorokin A, Burgess WH, Jaye M and Schlessinger J: Identification of six novel autophosphorylation sites on fibroblast growth factor receptor 1 and elucidation of their importance in receptor activation and signal transduction. Mol Cell Biol 16: 977-989, 1996.

17. Webster MK and Donoghue DJ: Constitutive activation of fibroblast growth factor receptor 3 by the transmembrane domain point mutation found in achondroplasia. EMBO J 15: 520-527, 1996.

18. Naski MC, Wang Q, Xu J and Ornitz DM: Graded activation of fibroblast growth factor receptor 3 by mutations causing achondroplasia and thanatophoric dysplasia. Nat Genet 13: 233-237, 1996.

19. Matsushita T, Wilcox WR, Chan YY, et al: The FGFR3 promotes synchondrosis closure and fusion of ossification centers through the MAPK pathway. Hum Mol Genet 18: 227-240, 2009.

20. Tanaka N, Katsumata N, Horikawa R and Tanaka T: The comparison of the effects of short-term growth hormone treatment in patients with achondroplasia and with hypochondroplasia. Endocr J 50: 69-75, 2003.

21. Tanaka H, Kubo T, Yamate T, Ono T, Kanzaki S and Seino Y: Effect of growth hormone therapy in children with achondroplasia: growth pattern, hypothalamic-pituitary function, and genotype. Eur J Endocrinol 138: 275-280, 1998.

22. Ramaswami U, Rumsby G, Spoudeas HA, Hindmarsh PC and Brook CG: Treatment of achondroplasia with growth hormone: six years of experience. Pediatr Res 46: 435-439, 1999.

23. Yamate T, Kanzaki S, Tanaka H, et al: Growth hormone $(\mathrm{GH})$ treatment in achondroplasia. J Pediatr Endocrinol 6: 45-52, 1993.

24. Escamilla RF, Hutchings JJ, Li CH and Forsham P: Achondroplastic dwarfism. Effects of treatment with human growth hormone. Calif Med 105: 104-110, 1996.

25. Seino Y, Yamanaka Y, Shinohara M, et al: Growth hormone therapy in achondroplasia. Horm Res 53: 53-56, 2000.

26. Wilkin DJ, Szabo JK, Cameron R, et al: Mutations in fibroblast growth factor receptor 3 in sporadic cases of achondroplasia occur exclusively on the paternally derived chromosome. Am J Hum Genet 63: 711-716, 1998. 